\title{
Is Arctic Governance Research in Crisis? A Pathological Diagnosis
}

Sebastian Knecht ${ }^{\mathrm{a}}$ and Paula Laubenstein ${ }^{\mathrm{b}}$

This is a pre-print of the manuscript published in revised form as follows:

Knecht $S$ and Laubenstein P. Is Arctic governance research in crisis? A pathological diagnosis. Polar Record 56(e35): 1-13. doi: https://doi.org/10.1017/S0032247420000352

a CORRESPONDING AUTHOR. Faculty of Sociology, Bielefeld University, email: sebastian.knecht@uni-bielefeld.de

a Faculty of Sociology, Bielefeld University, email: paula.laubenstein@uni-bielefeld.de 


\section{Abstract}

The governance of the Arctic as a frontier for international environmental and climate cooperation, resource politics and security governance holds the promise to provide important insights into some of the $21^{\text {st }}$ century's most enduring and pressing global challenges. This article reviews the state of the art of Arctic governance research (AGR) to assess the potential and limitations of a regional studies community for making sense of Northern politics and contributing to the broader discipline of international relations (IR) research. A bibliometric analysis of 398 articles published in ten outlets between 2008 and 2019 reveals that AGR faces at least four limitations that undermine understanding and explaining the processes and outcomes of regional politics and inhibit generalizable observations applicable to questions of global governance: academic immaturity, methodological monoculturalism, state-centrism, and analytical parochialism. The lack particularly of theoretically-driven and comparative research is indicative of a deeper crisis in AGR which, if unaddressed, could further solidify the community's unjustified reputation as quixotic in orientation and negligible in its contributions to IR research.

Keywords: Arctic governance; International relations; Review article; Academic development; Bibliometric analysis 


\section{Introduction}

Within only a few years' time, the Arctic, those marine areas and the adjacent landmasses of the USA, Canada, Russia, Norway, Sweden, Finland, Iceland and the Kingdom of Denmark north of $66^{\circ} 33^{\prime} \mathrm{N}$, has emerged as a distinct object of international governance and social science research alike (Hua, Yuan, Yan, \& Li, 2012). The Arctic is an exemplary world region for the intricacies of human-nature relationships and the complex entanglements of environmental, climate, resource and security governance at all levels from the very local to the international. The complexity of these governance questions and the short time horizon to respond to a rapidly changing and fragile environment exerts immense pressure on the multi-level governance system put in place over the past two decades to steer the future of the world's northernmost region (Keil \& Knecht, 2017a; Landriault, Chater, Wilson Rowe, \& Lackenbauer, 2019). Warming at twice the rate of the global average, the circumpolar North is all at once a signifier, victim and amplifier of the devastating effects of global climate change. In the words of former Finnish Minister of Foreign Affairs, Alexander Stubb, the Arctic 'is evolving from a regional frozen backwater into a global hot issue' (Stubb, 2009). In parallel to the wider public and political attention scholars with a variety of disciplinary backgrounds, from political science, international relations (IR) and international and public law to anthropology, history and geography, have turned towards the North for the study of contemporary challenges of global governance as diverse as multilateral diplomacy, indigenous and local politics, marine governance, geopolitics, great power competition, international security cooperation, science-policy interactions and the management of vulnerable socio-ecological systems (see for instance Brady, 2017; Burke, 2020; Grant, 2010; Kraska, 2011; Stone, 2015; Young, Berkman, \& Vylegzhanin, 2020; Zellen, 2009). 
Arctic change is to a great extent caused by global developments and has repercussions felt far beyond its boundaries. Against this background, scholars argue that the region is an often unrecognized focal point for the governance of many of the $21^{\text {st }}$ century's pressing international problems (see for instance Durfee \& Johnstone, 2019; Evengård, Larsen, \& Paasche, 2015; Young, 2019). Some further contend that in many ways the Arctic region transcends a global North/global South divide, Western/non-Western ontologies and imperialist ideas of centre-periphery relations (Dodds, 2018; Grydehøj, 2014; Olsen \& Shadian, 2018). A peripheral region only for those who stick to a map view of international politics, the Arctic has evolved into a 'global region' in which different norms, interests and policies from across the North American continent, Europe and South and East Asia intersect (Heininen \& Southcott, 2010). Herein lies a challenge and an opportunity for IR research. Making sense of Arctic governance in its local context and for the region and its peoples requires sustained efforts in 'homegrown theorizing' - 'original theorizing in the periphery about the periphery' (Aydinli \& Biltekin, 2018, p. 4). At the same time, learning from the specific case of Arctic governance promises insights and lessons also for other regions and global regime complexes, and can enrich empirical, conceptual and theoretical debates in IR and global governance more generally (cf. Acharya, 2014). Likewise, rigorously applying established concepts and theories from across the discipline of IR can help to better make sense of Arctic developments.

As a first step towards a deeper symbiosis between the field of Arctic governance research (AGR) and the discipline of IR, this article seeks to gain a deeper understanding of AGR and the toolbox of methodological, epistemological and ontological approaches the scholarly community devote to its study. Our interest in these parameters stems from contradictory statements in past commentaries that the Arctic as 'an extreme case can be a demanding and sometimes creative challenge to 
the theory used' (Wæver, 2017, p. 121), whereas in practice 'research on Arctic politics has only to a limited extent spurred theory-building or debate between (implicitly or explicitly defined) camps' (Østerud \& Hønneland, 2014, p. 171). One of the main reasons for this, as Hønneland suggests elsewhere, is that 'IR literature on the politics of the Arctic has been mainly empirical in orientation' and 'ff]ew contributions take their explicit point of departure in matters of theory' (Hønneland, 2016, pp. 16-17).

Beyond the necessity to track regional developments, exploring and ultimately explaining the Arctic as an 'archetype of the complex, multi-dimensional global problems of the twenty-first century' (Blunden, 2009, p. 137) holds promise for IR and global governance research as well. Not only is the Arctic undeniably of relevance as a resource base and regional security complex in international affairs, but some also consider the unique system of Arctic governance a role model for effective and inclusive global climate governance (Forbis \& Hayhoe, 2017; Koivurova, 2012). Understanding the structures and processes of the regional governance system with the Arctic Council in the centre thus can yield relevant results to that effect.

In this paper, we investigate the state of the art of the relatively young field of AGR through a bibliometric analysis of academic outlets that specifically focus on or regularly publish in the field. As a precaution, we consider it important to assure that we do not intend to judge individual contributions to the field and, more importantly, our review should not be read as an attack on any researcher's academic merit. Whenever we point to individual contributions or researchers throughout the analysis, we do so to highlight positive examples of the point we want to make. What we have configured here as a pathological diagnosis is one of the field to show where obstacles to academic progress prevail in a highly productive research community, not of the authors that contribute to it. This leads us to a second precautionary note. We do not suggest that the field of AGR is a sick patient or should be pronounced dead. As the 
review will show, the field is very alive and prospering, both in terms of research output and quality. We are more concerned with the issue of diversity of research objects and the methods and approaches used to study them that we think slows progress and keeps the field of AGR from assuming its rightful place in IR. The aim then is to conduct for the first time a comprehensive and systematic assessment of academic patterns and long-term developments in this particular IR subfield over a period of more than a decade from 2008 to 2019. The article scrutinizes how AGR has developed back to back with its object of study, and which paradigms, approaches and methodologies have been used for understanding, interpreting and explaining international governance in the Arctic. Reflection about the course of science can further help to identify past priorities, current research gaps and future needs in the study of the Arctic. Notwithstanding these opportunities for progress, the findings of this review suggest that AGR is often self-limiting in the sense that much potential of the field for empirical, conceptual and theoretical advancement is left unexploited. Just as much as the Arctic is often seen as politically detached from world affairs, the study of Arctic governance is overall decoupled from the wider IR discipline and neither downstreams existing knowledge, concepts and hypotheses for theory-testing nor upstreams localized research to inform theory-building and broader debates with relevance elsewhere on a larger scale.

The remainder of this article continues as follows. In the next section, we introduce our dataset of 398 peer-reviewed articles on Arctic international governance and describe in detail the data collection process, coding technique and analytical standards applied to assess how the field has developed over more than a decade and where it currently stands. We then analyse the dataset along a number of key parameters - research orientation, methodology, unit of analysis and level of analysis - and identify at least four central weak points of AGR: academic immaturity, 
methodological monoculturalism, state-centrism and analytical parochialism. We conclude the paper by problematizing these four limitations as severely diminishing the relevance of AGR for regional affairs and international relations, and make a couple of proposals to elevate the standing and importance of the field as a legitimate part of IR.

\section{Data and method}

We investigate what methods and analytical techniques AGR has applied to understand and explain the complexity of international politics in the Arctic over the period from 2008 to 2019. We are further interested in how research findings are related to the wider discipline of IR and global governance to stimulate empirical and theoretical debate. We take the year 2008 as the start for our bibliometric analysis as it marked a crucial turning point in Arctic history. Due to a combination of factors scientific reports about the fast degradation of the Arctic environment and the simultaneous increase in economic and political attention towards the region - public perception changed from an allegedly 'old' and 'regional Arctic' positioned in the periphery of both international politics and the IR discipline to what is now called the 'new' and 'global Arctic' characterized by a polyphony of regional and international issues, interests, imaginaries, institutions and involvements (Keil \& Knecht, 2017b). The choice of the period under investigation is further warranted on grounds of method and data collection since several new academic outlets on which the analysis is based were founded only after 2008 and in direct response to the growing political and academic interest in the region.

We identified altogether ten peer-reviewed journals that are prestigious, authoritative and widely read sources in the field of Arctic international governance and which together account for a substantial share of published research in that area. We had to exclude one more outlet that fulfilled our criteria, the Yearbook of Polar Law, 
due to access restrictions. As a threshold for inclusion in the sample, on average one article per year on international governance in the Arctic must have been published in the journal. Even among Arctic scholars, the term 'Arctic governance' is a hydraheaded catchword whose meaning lacks consensus so that it becomes difficult to pin down an understanding under which to subsume research published across the outlets (for discussions of the term, see Loukacheva, 2010; Pelaudeix, 2014). We opted for a broad understanding of Arctic international governance by applying Rosenau's classic definition of global governance as 'systems of rule at all levels of human activity - from the family to the international organization - in which the pursuit of goals through the exercise of control has transnational repercussions' (Rosenau, 1995, p. 13) to the regional context of the Arctic. This definition helps to distinguish the area of international governance from other disciplines of political science (such as comparative politics or public administration) and is at the same time sufficiently broad in scope to include different kinds of actors (both state and non-state), various institutions (both formal and informal) operating at different levels (national, regional and international), and the diversity of governance processes, mechanisms and outcomes, including but not limited to international policy coordination, knowledge exchange, norm creation, rule-making, regime formation and dispute resolution (both bilateral and multilateral). The inclusion of families as relevant international actors in Rosenau's definition may raise eyebrows especially among more traditional IR scholars. We agree with others that it serves the purpose of identifying actorness in Arctic/global governance empirically and not through predefined theoretical corsets, and that Rosenau may thus have meant it as 'a provocation to academics working in the field, intended to force analysts to ponder about the issue of scale, to give serious thought to the kinds of interlinkages that need analysis, and not to take for granted 
what theories of international relations conventionally assume to be the relevant actors of world politics' (Dingwerth \& Pattberg, 2006, p. 190).

Six of the ten journals self-identify as area-specific sources for AGR. These are Polar Record, The Polar Journal, Polar Geography, Arctic Review on Law and Politics, The Northern Review, and the Arctic Yearbook. The other four outlets in our dataset are broader disciplinary journals in the field of international law (Ocean Development \& International Law), IR (Cooperation and Conflict), foreign policy analysis (International Journal) and marine governance (Marine Policy). The diversity of selected journals produces a representative and unbiased sample of AGR. Some of the journals privilege more policy-relevant research (The Polar Journal, Marine Policy, International Journal) than others with a stated intention to publish rigorous theoretical and/or empirical research (e.g. Cooperation and Conflict, Ocean Development \& International Law). None of the outlets gives priority to any particular ontological or epistemological approach, method or theoretical school. Neither does any of the journals explicitly favour any single national perspective on Arctic politics. Finally, although the majority of journals are region-specific in their mission, this does not mean they promote an area studies agenda by nature highlighting the region's distinctiveness and therefore favouring 'thick description' of single cases that would divide the field from the wider IR discipline (cf. Bates, 1997). Whether to conduct more empirical or theoretical work is a deliberate choice by each individual scholar, not the journals in which the research results are published.

After having identified the ten outlets, we consulted the abstracts of all articles in each published issue on the journals' websites since 2008 (or the year the outlet was launched after that) in order to determine whether they met our understanding of Arctic international governance. With regard to the type of the published material, we limited the selection to research articles and academic commentaries that met the 
proposed definition of Arctic international governance and excluded editorials, review articles, book reviews and letters to the editor. Table 1 shows a comparison of all outlets in the dataset and the number of Arctic IR articles published per outlet and year between 2008 and 2019. Our selection procedure resulted in a total of 398 articles. Over the entire period, the number of articles per outlet varies from thirteen (Cooperation and Conflict) to 98 (Arctic Yearbook). Unsurprisingly, the four disciplinary journals published fewer articles on Arctic governance than most of the area-specific journals. On average, 33 articles on Arctic international governance are published per year across the sample. While the number of articles per year has increased considerably over time and reached a peak of 55 articles in 2016, the growth in AGR over time can be mostly attributed to the addition of three new outlets between 2010 and 2012 (Arctic Review on Law and Politics, The Polar Journal, Arctic Yearbook), with the Arctic Yearbook producing the largest share of articles in most years.

\begin{tabular}{|c|c|c|c|c|c|c|c|c|c|c|c|c|c|c|c|}
\hline Journal & Est. & ঃ̊ & 용 & 웅 & Г̃ & กั & ำ & $\frac{\text { d }}{\mathbf{S}}$ & ำ & $\frac{0}{2}$ & స్ํำ & $\stackrel{\infty}{\circ}$ & হ) & $\begin{array}{l}\text { No. of } \\
\text { articles }\end{array}$ & $\begin{array}{c}\text { Share } \\
\text { in } \\
\text { dataset } \\
\text { (in \%) }\end{array}$ \\
\hline $\begin{array}{l}\text { Cooperation and } \\
\text { Conflict }\end{array}$ & 1965 & 2 & 0 & 0 & 1 & 0 & 1 & 3 & 0 & 2 & 1 & 1 & 2 & 13 & 3.27 \\
\hline $\begin{array}{l}\text { The Northern } \\
\text { Review }\end{array}$ & 1988 & 0 & 0 & 0 & 6 & 1 & 6 & 0 & 1 & 1 & 0 & 1 & 0 & 16 & 4.02 \\
\hline $\begin{array}{l}\text { Polar } \\
\text { Geography }\end{array}$ & 1977 & 0 & 0 & 0 & 2 & 1 & 2 & 5 & 2 & 2 & 4 & 4 & 3 & 25 & 6.28 \\
\hline $\begin{array}{l}\text { International } \\
\text { Journal }\end{array}$ & 1946 & 2 & 1 & 12 & 8 & 2 & 0 & 1 & 2 & 1 & 0 & 1 & 4 & 34 & 8.54 \\
\hline Marine Policy & 1977 & 2 & 0 & 0 & 3 & 1 & 1 & 2 & 4 & 8 & 5 & 4 & 5 & 35 & 8.79 \\
\hline $\begin{array}{l}\text { Ocean } \\
\text { Development \& } \\
\text { Internat. Law }\end{array}$ & 1973 & 1 & 5 & 0 & 6 & 3 & 4 & 4 & 2 & 3 & 1 & 3 & 4 & 36 & 9.05 \\
\hline $\begin{array}{l}\text { Arctic Review on } \\
\text { Law and Politics }\end{array}$ & 2010 & - & - & 5 & 1 & 4 & 1 & 1 & 2 & 5 & 5 & 9 & 2 & 35 & 8.79 \\
\hline $\begin{array}{l}\text { The Polar } \\
\text { Journal }\end{array}$ & 2011 & - & - & - & 0 & 6 & 8 & 7 & 3 & 7 & 5 & 2 & 7 & 45 & 11.31 \\
\hline Polar Record & 1931 & 1 & 5 & 4 & 4 & 3 & 5 & 6 & 6 & 13 & 9 & 3 & 2 & 61 & 15.33 \\
\hline Arctic Yearbook & 2012 & - & - & - & - & 14 & 11 & 4 & 13 & 13 & 12 & 15 & 16 & 98 & 24.62 \\
\hline Total & & 8 & 11 & 21 & 31 & 35 & 39 & 33 & 35 & 55 & 42 & 43 & 45 & 398 & 100 \\
\hline
\end{tabular}


Following the sample selection, we collected information on several parameters through a close reading of the full text, including the article's research orientation, methodology, unit of analysis and analytical focus.

Regarding the first of the four parameters, we distinguished between six research orientations: descriptive, conceptual, theory-testing, theory-generating and instrumentally or normatively prescriptive papers. The primary purpose of descriptive papers is to inform about, review or assess political developments, e.g. an actor's interests and strategy in the Arctic or law-making processes in international institutions, but without the paper being embedded in a theoretical framework or broader research agenda, producing generalized statements beyond the case, and in some instances even without posing a research question. Conceptual papers seek to introduce, specify or reinterpret concepts from across the social sciences, law, geography or other fields of study. Examples of this kind include concepts like 'sustainability', 'human security', 'geopolitics' or 'Arctic regionalism'. Theory-testing articles deductively apply conventional IR theories to the case of the Arctic in order to either test the validity of hypotheses or causal mechanisms proposed by a theory in order to confirm them or to explain the 'Arctic case' from a certain theoretical perspective. Theory-generating articles, on the other hand, aim at inductively putting forward or developing new hypotheses, causal mechanisms or entire theoretical constructs following abstraction from the specificities of the Arctic case. Finally, one broader category consists of papers that are primarily prescriptive in nature and directed at policy-making. Prescriptive papers can be instrumental or normative at their core, depending on whether the intention is to improve policy or emphasize a desired policy goal. Though articles can sometimes combine two or more of those categories - most theory-driven research relies on conceptual work or instrumental policy recommendations are 
informed by normative beliefs of the author(s) - we opted for an unambiguous classification of borderline cases based on what in the reading process appeared to be the article's main purpose.

For the second parameter - methodology - we coded statistical analyses with a high number of cases as 'quantitative' and the analysis of one or a few cases as 'qualitative' with further subdividing the latter category into 'single-case studies' and 'comparative case studies'. Our coding scheme was flexible enough to allow for additional methods to be categorized inductively throughout the review process, but as the empirical analysis will show, those have not appeared. Though not a method in a strict sense, one additional category that came up in the coding process includes papers that make a purely 'theoretical argument' free from any empirical analysis.

Our third and fourth parameters cover the analytical focus in the published work in terms of an article's unit of analysis and its level of analysis. Those two should not be confused (cf. Yurdusev, 1993). The choice of the unit of analysis in IR is first and foremost an ontological postulate privileging a certain research object for study over others, often but not necessarily an actor-type like an individual, a group, a corporate actor, a nation, a state or an international organization. But a unit of analysis can also be a discourse, norm, legal principle or a spatial entity such as the Arctic region itself. Levels of analysis are distinct from units in that they do not constitute entities, but demarcate a social context in which those actor units operate and by which they are constrained in their behaviour, such as neighbourhood, society, regional community or the international system. The level of analysis serves as a heuristic device to identify the 'social structures that exist as levels in relation to a unit of analysis whose behaviour or properties the level's own properties are examined to explain' (Temby, 2015, p. 738). Although unit and level of analysis are two separate analytical categories, they interact to form a co-constitutive agent-structure relationship that 
allows us to draw conclusions about scholars' research preferences for which actors matter in Arctic international governance and by what societal or structural conditions their actions are possibly shaped.

Because the Arctic region is subject to a complex web of national, circumpolar and international rules and institutions, determining the unit of analysis generates important insights into what actors, aspects or components of the Arctic regime complex researchers consider particularly relevant. Six specific units of analysis have emerged from the coding process, three of which represent actor units: 'state', typically Arctic and non-Arctic states, 'non-state actors' like the World Wide Fund for Nature or the Inuit Circumpolar Council and 'international organizations' like the Arctic Council, the EU or the International Maritime Organization (IMO). Other articles deal with 'international regimes' as distinct from international organizations, for example the UN Convention on the Law of the Sea, the Svalbard Treaty, the IMO's Polar Code or the various legally-binding agreements negotiated under the Arctic Council, or they focus on the interaction between several institutions coupled in an 'Arctic regime complex' as unit of analysis. Moreover, a considerable number of articles took a bird's-eye view on the political order in the Arctic or treated the circumpolar region as a whole, or parts of it, as geographical 'region' unit. We have further grouped together 'narratives' about the past, present and future Arctic as they become the primary object in political, media and popular discourse as a sixth unit of analysis.

For the majority of articles that have an actor as central object of study (69 \% of the sample), unit and level of analysis can be meaningfully combined for diagnostic purposes. Four combinatory possibilities exist for the study of Arctic international governance depending on whether or not the unit of analysis is located inside the Arctic region (Arctic/non-Arctic) and whether the context of that actor's operation is the circumpolar level of Arctic-specific regimes or the wider international domain of Arctic- 
relevant governance institutions (regional/international): inward-oriented, outwardoriented, inside-out and outside-in approaches (for a similar, three-type distinction applied to EU foreign policy analysis, see Keuleers, Fonck, \& Keukeleire, 2016). Analysing the published material along these four approaches and over time can help to identify continuity and changes in the analytical orientation of Arctic scholarship, highlight where research has fixated on particular units or stayed within the boundaries of certain levels, and reveal where it may have omitted others. Articles that focus on an actor located inside the circumpolar region (Arctic/regional), one example of which is Sergunin's and Konyshev's analysis of Russia's interests, strategies and policies towards the Arctic (Sergunin \& Konyshev, 2014), were categorised as inward-looking approaches. If, on the other hand, the research object was a non-Arctic actor (nonArctic/regional), as for instance in Kopra's investigation of China's turn towards the Arctic (Kopra, 2013), the analytical approach was coded as outside-in. The approach changes to outward-looking whenever an article emphasises the international level of Arctic-relevant institutions or a non-Arctic actor's role in it (non-Arctic/international). One such example is Bognar's analysis of the negotiations leading to the adoption of the IMO's Polar Code (Bognar, 2018). The complementary fourth perspective is an inside-out approach where the level of analysis remains the international, but the unit of analysis is an Arctic actor (Arctic/international). Rottem's discussion of how Norway has been successful in listing persistent organic pollutants to the Stockholm Convention with the objective of promoting Arctic environmental protection is a fitting example (Rottem, 2017).

Most of the articles in the dataset could be assigned to one of the four analytical categories, and to one category only. A minor share of eight articles (about $2 \%$ ) has combined an inward-looking with an outside-in approach, for instance by comparing 
an Arctic with a non-Arctic state's role in regional affairs (see for instance Lundestad \& Tunsjø, 2015 for a comparison of US and Chinese Arctic policies).

\section{Findings}

The results of our analysis of 398 articles in the dataset suggest that AGR faces at least four limitations. These limitations concern essential parameters of how research and analysis of Arctic international governance are conducted and which, if they are to continue, in our view can potentially undermine the further relevance of the field as currently practiced. We identify these four limitations as academic immaturity, methodological monoculturalism, state-centrism and analytical parochialism. These four limitations have permeated AGR to an extent where they have become deeply entrenched habits. These habits can negatively impact academic progress in the field and thwart valid and reliable inferences from the results they produce. We will go through each one by one in the following presentation of the empirical record of our dataset.

\section{Academic immaturity}

The first limitation which we call academic immaturity concerns the kind of knowledge AGR produces as well as the means of its production. Going back to Max Weber's lecture on 'science as a vocation' in 1918, Robert Keohane several years ago sketched a stage model for political science as a vocation, starting with the two basic but essential tasks of (1) identifying puzzles worthy of deeper consideration and (2) defining and operationalizing the concepts used to address a puzzle, to two more advanced stages of (3) drawing descriptive conclusions from observed data to a broader population and (4) making inferences about cause-effect relationships (Keohane, 2009). Although Keohane mentions a fifth task between stages (2) and (3), 
that of 'simple description', in passing, it is telling that he does not give it any further consideration.

Though it comes with its own challenges, description is seen by some as an intellectually easy, relatively unchallenging and ultimately subordinate task to causal analysis, one 'without which science would not be possible but which does not by itself constitute science' (King, Keohane, \& Verba, 1994, p. 34). Of course, description can serve independent purposes from causal inference. It is a necessary component of all scientific conduct and can add up to a stockpile of basic knowledge to inform both policy and research. Gerring identifies five different forms of descriptive arguments, distinguishing between, on the one hand, particularizing 'accounts' of a single event to, on the other, 'indicators', 'associations', 'syntheses' and 'typologies' which aim at generalization (Gerring, 2012, pp. 724-729). And yet, even Gerring's taxonomy of the independent roles of description in political science besides causal analysis is no call for descriptive work to be carried out entirely without causal analysis. Rather, the two depend on each other, and Gerring insists that 'the paradigmatic shift from description to causation qualifies as a mark of disciplinary maturity' (Gerring, 2012, p. 730).

When assessed against the taxonomy of descriptive arguments, much of AGR stays within the limits of 'accounts'. Such descriptive accounts in Gerring's view are 'particularistic' in that they 'refer to any analysis of an event or set of events with no explicit attempt to generalize beyond the specifics of a particular case' (Gerring, 2012, p. 725). On their own, purely descriptive accounts are of importance only for a small number of policy-makers and region specialists to keep track of local developments. For the same reason, descriptive accounts are of only temporary value and often outrun by events, and thus require constant reassessment that can bind a substantial part of available resources and research capacities, particularly in small academic 
communities. That way, too much description can lead to saturation, not stimulation, of a research field.

Our analysis finds that AGR is in a state of academic immaturity in the sense that it overwhelmingly relies on simple description as a form of knowledge generation as disregarded by Keohane and criticized by Gerring. Nearly half of the articles in our dataset $(48 \%, n=191)$ fall in the category of descriptive analysis. Emerging research fields such as Arctic governance studies of course require a comprehensive empirical record of the research object in all its facets. Identifying research puzzles, empirical categories, relevant inconsistencies in data and variations for further analysis requires that researchers first know the facts. Without proper accumulation of empirical knowledge, there is little to theorize about or to feed into descriptive and causal inference.

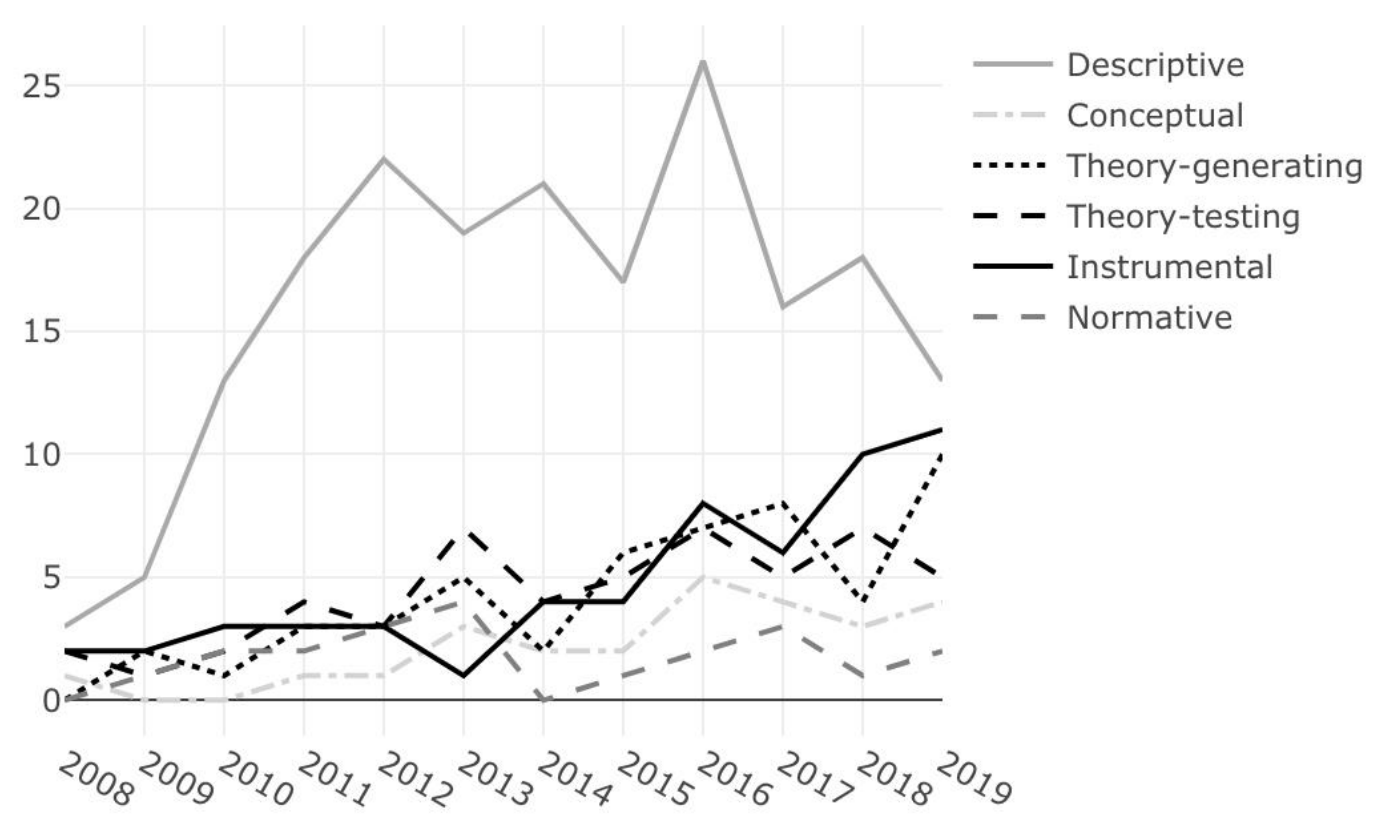

Fig. 1: Development of research orientations over time, 2008 - 2019 (in absolute numbers per year)

Source: Authors' own compilation 
Still, two developments can be seen as troubling for the field. First, the number of descriptive accounts constantly exceeds any other research orientation over the entire investigation period (see Fig. 1). After a few papers with different research orientations had been published on AGR in 2008, description skyrocketed to a first peak in 2012 when it accounted for more than 60 percent of all published work in the field. Over the period from 2008 to 2012, about 58 percent of all papers were descriptive accounts $(n=61)$. Their massive increase early on indicates a high demand for the accumulation of basic knowledge about Arctic politics and governance that had not drawn much attention in the discipline of IR until then. Indeed, all eight Arctic states adapted quickly to the new realities of a changing North and adopted Arctic strategies or policy documents between 2006 and 2011 (Heininen, 2011). Those were of primary interest in the first half of the investigation period. More than every second article between 2008 and 2012 had a focus on the eight Arctic states and their interests and policies in the region ( $59 \%, \mathrm{n}=36)$. Far behind follow descriptions of Arctic-specific or -relevant regimes $(13 \%, n=8)$, structural perspectives on the Arctic region $(11 \%, n=7)$ and examinations of the roles of three international organizations - the Arctic Council, the EU and the IMO - in regional affairs $(10 \%, n=6)$. Three papers in this first period address non-state actors (5\%) and another one the use of narratives in power politics in the region $(2 \%)$.

Though the development of descriptive articles is more fluid in the period from 2013 to 2019 , they continue to make up the large majority of papers reaching the highest absolute number for a single year in $2016(47 \%, n=26)$. On average, 45 percent of all articles in this period $(n=130)$ fall into the category of descriptive accounts, indicating only a slow change in research orientations in comparison to the first period. Remarkably, the share of state-centred papers increased in this second 
period up to 65 percent of all descriptive accounts, to be explained mainly by a shift from Arctic towards non-Arctic states and here particularly the five Asian states China, India, Japan, Singapore and South Korea following their admission to the Arctic Council as observer states in 2013. Without descriptive accounts of non-Arctic states, the relative share of papers focusing exclusively on the eight Arctic states would have dropped to about 35 percent $(n=45)$. Almost every second state-centred description between 2013 and 2019 involves at least one non-Arctic state $(n=39)$. As a consequence, the margin between state and other units of analysis in descriptive accounts has remained overall unchanged. Regime analyses come second (15\%, $\mathrm{n}=20)$, followed by international organizations $(11 \%, \mathrm{n}=14)$ and region $(7 \%, \mathrm{n}=9)$. Only one paper each deals with non-state actors and narratives.

Second, the high share of simple description in AGR also stands out because it does not seem to translate into a larger body of explanatory causal analysis. The other half of the dataset $(52 \%, n=207)$ is composed of a hodgepodge of conceptual, prescriptive and theory-guided research. Conceptual interventions account for about seven percent of all papers $(n=26)$ in the dataset and show a modest increase over the investigation period. Every fifth paper in the dataset is prescriptive in essence (20 $\%, n=78$ ), whereby the large majority of these papers address instrumental questions of how to improve institutions or policies $(73 \%, n=57)$ and a minority takes a normative direction at favourable outcomes $(27 \%, n=21)$. The overall development shows that AGR is to a large extent a practical field of study to the benefit of policy and policymakers. Depending on one's own vision for the Arctic studies community and the purpose of social science research in general, the policy-orientation in much of AGR may certainly be regarded as a particular strength of the research community. Over time, prescriptive instrumental articles have become the second largest category of papers after descriptive accounts and steadily increased in number since 2013. Many 
of these articles deal with questions of marine governance, environmental, pollution and resource management, the design of international regimes or the effectiveness of the Arctic Council. Normative papers predominantly discuss the rights and participation of indigenous populations in Arctic governance arrangements.

Overall, only about every fourth paper in the dataset has an explicit theoretical angle (26\%, $n=103)$. Explanatory articles applying conventional IR theories to the case of the Arctic in order to test hypotheses or causal mechanisms have always existed over the time period, with little peaks in 2013, 2016 and $2018(n=52)$. On the other hand, theory-generating articles aiming at developing new theoretical insights from the case of the Arctic have emerged at a slow pace between 2008 and 2013 and increased substantially only after $2014(\mathrm{n}=51)$.

\section{Methodological monoculturalism}

The choice of method in social science research always involves multiple trade-offs regarding, among others, research objectives, causal inferences, validity claims, measurement, and the requirements for data collection and analysis. Such considerations often drive the research approach and particularly whether to use qualitative or quantitative techniques for data analysis (Goertz \& Mahoney, 2012). The distinction between qualitative and quantitative methods can be thought of as a continuum along two inversely related dimensions of case-specific knowledge and generalizability. A single-case study requires a high level of case-specific knowledge, while the specific context and characteristics of the case do not travel easily across cases. Quantitative analyses, in turn, relinquish case-specific knowledge for a variablebased approach tested across a large number of cases from which often more generalizable results can be drawn. 
It is against this background that we criticize the extent to which the single-case study is the default choice of method in AGR that comes close to a methodological monoculture. Three out of four papers $(75 \%, \mathrm{n}=299)$ in the field are single-case studies. Fig. 2 shows the distribution of methodological approaches in AGR in absolute numbers. Single-case studies have dominated the field throughout the entire period and have proven remarkably sustainable from being the preferred method in all papers in the first year of the dataset $(100 \%, n=8)$ to still being used in 78 percent of all papers in $2019(n=35)$.

Comparing research orientations and methodologies used in AGR, there appears to be a strong correlation between descriptive work and a single-case study design. Both follow the same trend over the investigation period. Seventy-five percent of all descriptive papers are single-case studies $(n=143)$ which can be read as AGR producing a lot of 'thick description' of individual Arctic actors, institutions and policies but lacking a comparative perspective that could reveal categorical differences, variations and contradictions in design and outcome for further empirical analysis. Comparative description accounts for 24 percent in the dataset $(n=46)$, while two descriptive accounts use quantitative methods (1\%). 


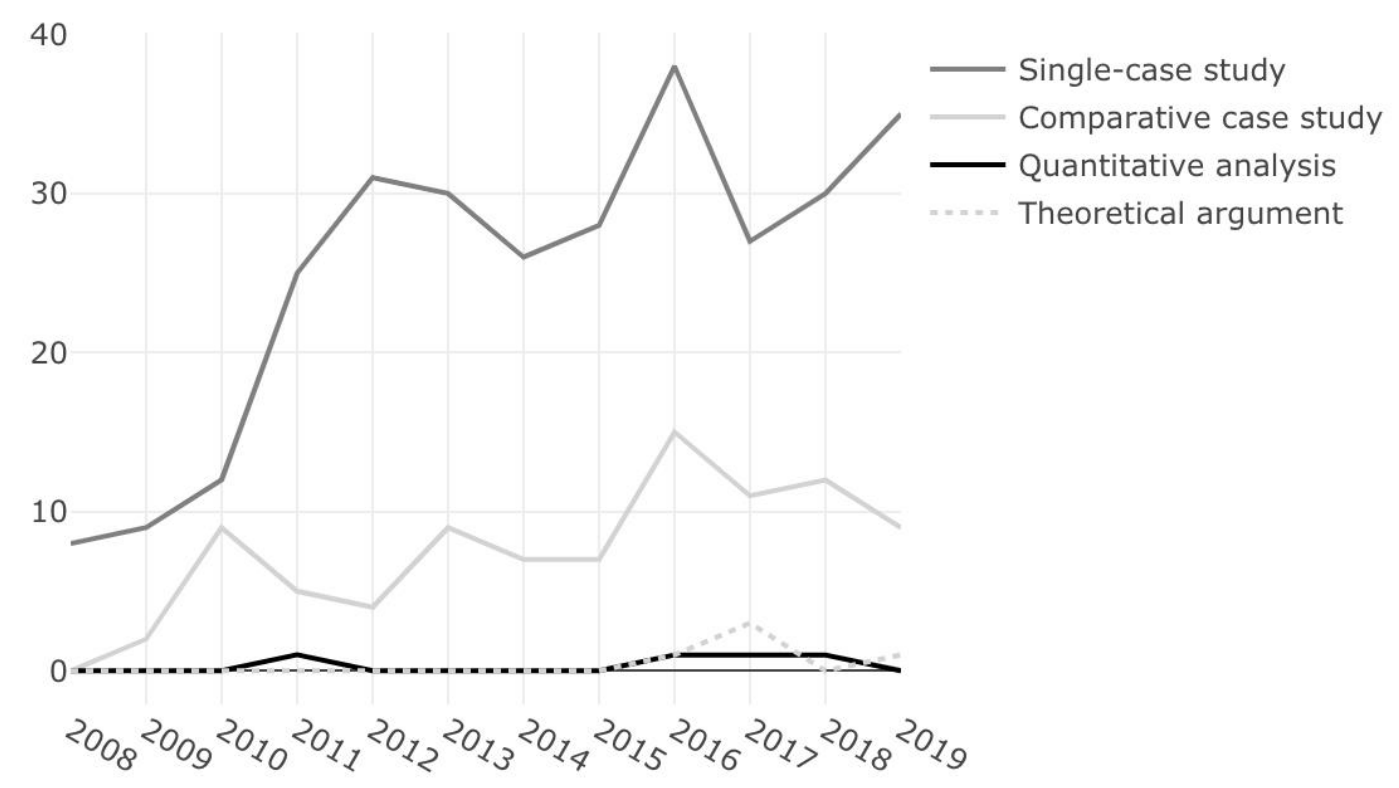

Fig. 2: Development of methodological approaches over time, 2008 - 2019 (in absolute numbers per year)

Source: Authors' own compilation

We do not suggest that one approach, qualitative or quantitative, is superior to the other or that the attentive exploration of a single-case is of lesser merit than large- $\mathrm{N}$ analyses. This is a matter of how researchers value the trade-offs between the two approaches. The point we intend to make is that Arctic researchers should be more aware of the advantages and disadvantages of their choice of method, particularly with regard to the limited generalizability of single-case studies, for ' $[t]$ he utility of a case study mode of analysis is in part a product of the scope of the causal argument that a researcher wishes to prove or demonstrate' (Gerring, 2007, p. 48). This should be given particularly careful consideration in light of the view held by some in the AGR community that Arctic peace and cooperation is an empirical anomaly - and the Arctic thus a deviant case - in international affairs. If the assumption of 'Arctic exceptionalism' holds true (e.g. Exner-Pirot \& Murray, 2017), there would be little more to learn from 
Arctic case study analysis than about the Arctic case itself because the peculiarities assumed for the Arctic do not easily apply in other world regions or social contexts. Under the assumption that the Arctic constitutes a deviant case in international politics, the dilemma of generalizing from Arctic case study analysis is not limited to the regional level when making inferences from the Arctic to other regions, but further trickles down to the national level where comparative work is more common. In the analysis of Arctic states' interests, policies and strategies, the notion of Arctic exceptionalism is often dropped silently so as if the eight Arctic states are comparable by nature simply because of their commonality of being located in the Arctic region. This view denies the often sharp distinctions in these states' political systems, processes, motives, capacities and actions that would make for instance Russia's authoritarian regime and the liberal democracies of the other seven Arctic states hardly comparable, even though they appear in almost every second comparative case study with the state as unit of analysis (46\%, $n=26$ ). We do not oppose such comparison in principle but intend to point out that also the subregional, national and subnational levels of the Arctic governance complex are often unique and constitute a variety and diversity of Arctic political contexts. In our view, these exceptionalisms too should be given greater attention in comparative research designs (see for instance Landriault et al., 2019).

The weaknesses of a case-based approach should not lead to the conclusion that a cure is to be found in a variable-based approach instead. The constraints of methodological monoculturalism are not easily resolved by shifting to more quantitative analysis. And neither are the prospects for such a turn promising. For that, the range of application for quantitative methods in a purely regional context is too restricted due to the low number of cases available. The Arctic governance regime composed of eight Arctic states and, in an extended view, thirteen non-Arctic states currently holding observer status with the Arctic Council is no exception. By date of admission, the 
observer states to the Arctic Council are Germany, the Netherlands, Poland, the United Kingdom (all 1998), France (2000), Spain (2006), China, India, Italy, Japan, the Republic of Korea, Singapore (all 2013) and Switzerland (2017). The number of Arctic and non-Arctic states would qualify for the application of other tools for causal analysis such as set-theoretic methods which require a medium number of cases, though (Ragin, 2008). It is no surprise then, and certainly no failure, that quantitative analyses have not featured prominently in AGR, and that the few studies in our dataset applying quantitative techniques for descriptive or estimative purposes do not focus (exclusively) on the state as unit of analysis but other variables of interest (Knecht, 2017b; Landriault \& Minard, 2016; Parsons, Dinwoodie, \& Roe, 2011; VanderBerg, 2018).

And yet, the single-case study method is not without alternatives. About 23 percent of the articles in our dataset $(n=90)$ are comparative case studies with at least two and a maximum of eight cases. The majority of these papers compare Arctic states and their regional interests, strategies or policies $(62 \%, n=56)$, though often they focus on single events within a short timeframe that do not allow for long-term assessments to explore continuities and change in Arctic foreign policies. A huge gap exists to the second largest set of comparative analyses that concentrate on regimes applicable to the Arctic $(12 \%, n=11)$, followed by research on international organizations, competing narratives and the Arctic region as a case of comparative regionalism (each $6 \%, n=5$ ). Only three comparative case studies look at non-governmental actors (3\%) and the remaining six percent at other units $(n=5)$.

\section{State-centrism}

A third limitation of AGR is rooted in overreliance on the state as unit of analysis in contrast to alternative units. Where AGR holds great potential to inform IR research, 
that is, to name a few, in the study of networked governance, multi-stakeholder collaboration, science-policy interactions and indigenous ontologies, it often falls back on traditional notions of state security, sovereignty and geopolitics. The sovereign state is the primary unit of analysis in 53 percent of AGR ( $n=209)$. In 202 out of these 209 articles, the state is the sole unit of analysis. A minority of seven papers has a mixed unit of analysis involving at least one state complemented with an analysis of international organizations ( $E U$, Arctic Council; $n=4$ ) or comparison with non-state actor units $(n=3)$. International regimes come second as unit of analysis $(14 \%, n=57)$, followed by international organizations $(13 \%, n=53)$ and the Arctic region as a spatial entity $(13 \%, n=52)$. Research on the role and impact of non-state actors is the rare exception and only accounts for four percent of all papers $(n=14)$. Three percent $(n=10)$ of the papers analyse discourses and narrative constructions, and one percent other units (ports, individuals, subnational territory) $(n=3)$.

In the category of international organizations, the Arctic Council stands out as a research object. About 60 percent of the research on international organizations deal with matters related to the preeminent regional forum for Arctic governance $(n=32)$. Another 23 percent concern the EU $(n=12)$, while the residual share of 17 percent divide between organizations like the IMO, the North Atlantic Treaty Organization (NATO) and the UN Permanent Forum on Indigenous Issues, but also includes papers that call for the establishment of entirely new organizations for issue-specific governance for instance in the central Arctic Ocean $(n=9)$.

Astonishing is particularly the weak position of indigenous populations in AGR that were here counted as part of the non-state actor unit. To be fair, indigenous involvement in the Arctic governance complex is often seen as one of its strongest assets and attracts a lot of attention in social science research (e.g. Eriksen, Valkonen, \& Valkonen, 2019; Herrmann \& Martin, 2016; Nuttall, 1998). Much of this scholarship 
takes place in local, societal and national contexts or address state-indigenous relations. A careful reading of the articles in our dataset leaves the (subjective) impression that also in the field of international governance as defined here are Arctic indigenous populations and their knowledges, histories, cultures, political and legal rights often paid lip service to. However, as a unit of analysis they are often in a subordinated role to that of the state, regimes or organizations. The bare figures in our dataset suggest that AGR is little different from IR research generally, for which a recent review found that it was 'almost completely silent on Indigenous peoples, their diplomacies, and the distinctly non-Western cosmologies that underwrite and enable them' (Beier, 2009, p. 11). There is no sign that this trend is somehow going to change anytime soon. Far from it, the gap between state and other units has recently widened (see Fig. 3). Most units have remained stable at relatively low levels over the investigation period, with the study of international organizations, regimes and structural perspectives on the Arctic region having lost ground in the past few years after a steady increase between 2008 and 2016. In contrast, the state unit has only seen a sharp upward trend over the entire period and in the last year of the dataset, in 2019, accounted for 60 percent of all papers, the last time it did in 2014. 


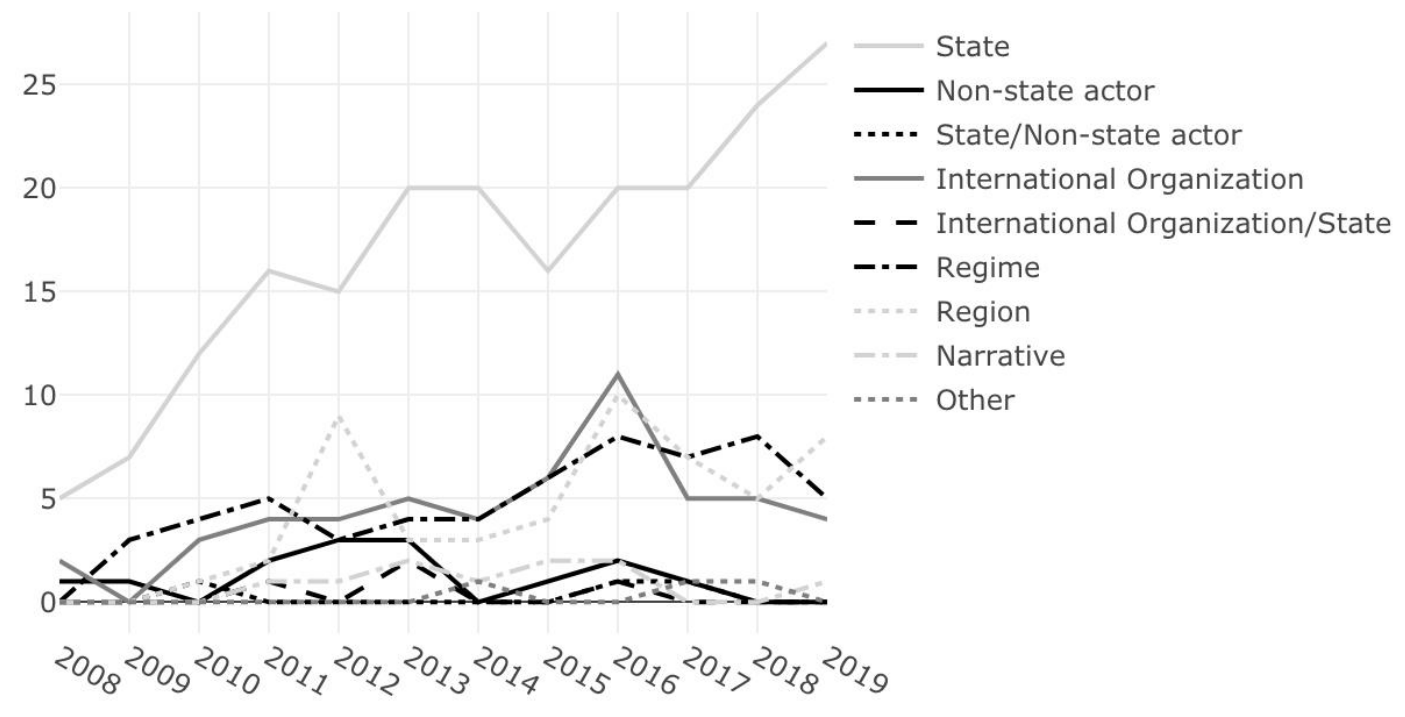

Fig. 3: Development of unit of analysis over time, 2008 - 2019 (in absolute numbers per year) Source: Authors' own compilation

Although AGR is preoccupied with state-based ontologies, there exists a strong disparity regarding which states are researched. Most papers address the five Arctic Ocean littoral states (so-called A5), among which the highest number of case studies account for Russia ( $n=56)$, followed by Canada $(n=51)$, Norway $(n=48)$, the United States $(n=28)$ and Denmark ( $n=27$ including analyses of Greenland $[n=11])$. The three Nordic countries Iceland $(n=7)$, Sweden $(n=6)$ and Finland $(n=4)$, often referred to as non-littoral states located in the sub-Arctic, receive significantly less attention.

Striking differences also exist across non-Arctic states admitted as observers to the Arctic Council and between them and the Arctic states. Arctic states $(n=227)$ are more than three times more often analysed than non-Arctic states $(n=66)$. This in itself is little surprising, but it should be noted that the total number of analyses of non-Arctic states would be even much lower when only China, which is the focus of about half of all non-Arctic case studies ( $n=34)$, was subtracted out. Even within the group of Asian observers, the gap to Japan ( $n=10)$, India and South Korea (each $n=4)$ and Singapore 
$(n=2)$ is huge. Asian observers together account for 82 percent of non-Arctic case studies and European observers for 18 percent. There are almost as many investigations into Japan's Arctic policy alone than for the eight European observer states combined. While the United Kingdom ( $n=7)$, Germany $(n=3)$, France and Poland (each $n=1$ ) have drawn at least some attention, Italy, the Netherlands, Spain and Switzerland have not appeared in one single study over the investigation period.

This blind spot leaves out some interesting historical and comparative perspectives, for instance the Arctic interests, policies and strategies of long-standing European observers with access to the Arctic Council since 1998 and those of the five Asian observers admitted in 2013, the comparative performance of European newcomers that have been admitted along with or after the five Asian states (Italy 2013, Switzerland 2017), or the different 'worlds of commitment' (Knecht, 2017a) in terms of participation and contribution across all observers as well as within the groups of European and Asian observers. Addressing these open questions requires to break with the tradition of treating European and Asian states as two separate and in themselves homogenous observer communities. A true global perspective on Arctic governance would further disengage from taking Arctic Council participation as a sole indicator for interest in Arctic affairs. So far, only one paper over the entire period has looked beyond the group of Arctic Council member and observer states to also consider the Arctic interests of Brazil and South Africa (Lagutina \& Leksyutina, 2019).

\section{Analytical parochialism}

One final limitation of $A G R$ is its overemphasis of the region as predominant level of analysis. While it is more and more acknowledged that Arctic governance is subject to local-global interactions of complex international cause-effect relationships, and thus should be understood as a 'globally embedded space' (Keil \& Knecht, 2017b), it is still 
mostly treated within the confines of isolated regional affairs and institutions. Inwardlooking and outside-in perspectives differ with regard to the location of the unit of analysis but take both the regional level as the relevant arena of Arctic governance. Together, they account for 86 percent of all papers ( $n=341)$, with 67 percent belonging to the category of inward-looking perspectives $(n=268)$ and 16 percent to the category of outside-in perspectives $(n=64)$. Nine more papers combine an inward-looking with an outside-in perspective by comparing regional with non-regional actors or institutions (3\%).

Although the absolute number of inward-looking perspectives is, as shown in Fig. 4, by far the highest in each year and continuously rising at least until 2016, their relative share in the dataset has been on the decline from a peak of 91 percent in 2009 $(n=10)$ to 58 percent in $2018(n=25)$. As the figure further shows, this decline can be mainly attributed to a significant drop inside this category after 2016 that was not compensated by an increase of papers with alternative perspectives. In consequence, the relative share went up to 67 percent in 2019 when again more papers with a purely regional perspective were published and all three alternative perspectives decreased in number.

Research with an outside-in perspective looks mostly at non-Arctic states and their involvement in regional affairs. Papers in this category emerged in the wake of the Asian enlargement of the Arctic Council in 2013 and have gone up and down after reaching a high of 31 percent of all papers in $2012(n=11)$. Over the entire investigation period, one quarter of outside-in perspectives analyse the European Union's Arctic interests and policies ( $n=16)$, which places the EU second after China (42\%, $n=27)$ but far ahead of the other European and Asian state observers, which combined make up 30 percent of the papers $(n=19)$. Two papers examine the consequences of the 
Ukraine conflict for Arctic security (3\%). There was not a single paper published on the external influence of non-state actors in any of the ten outlets.

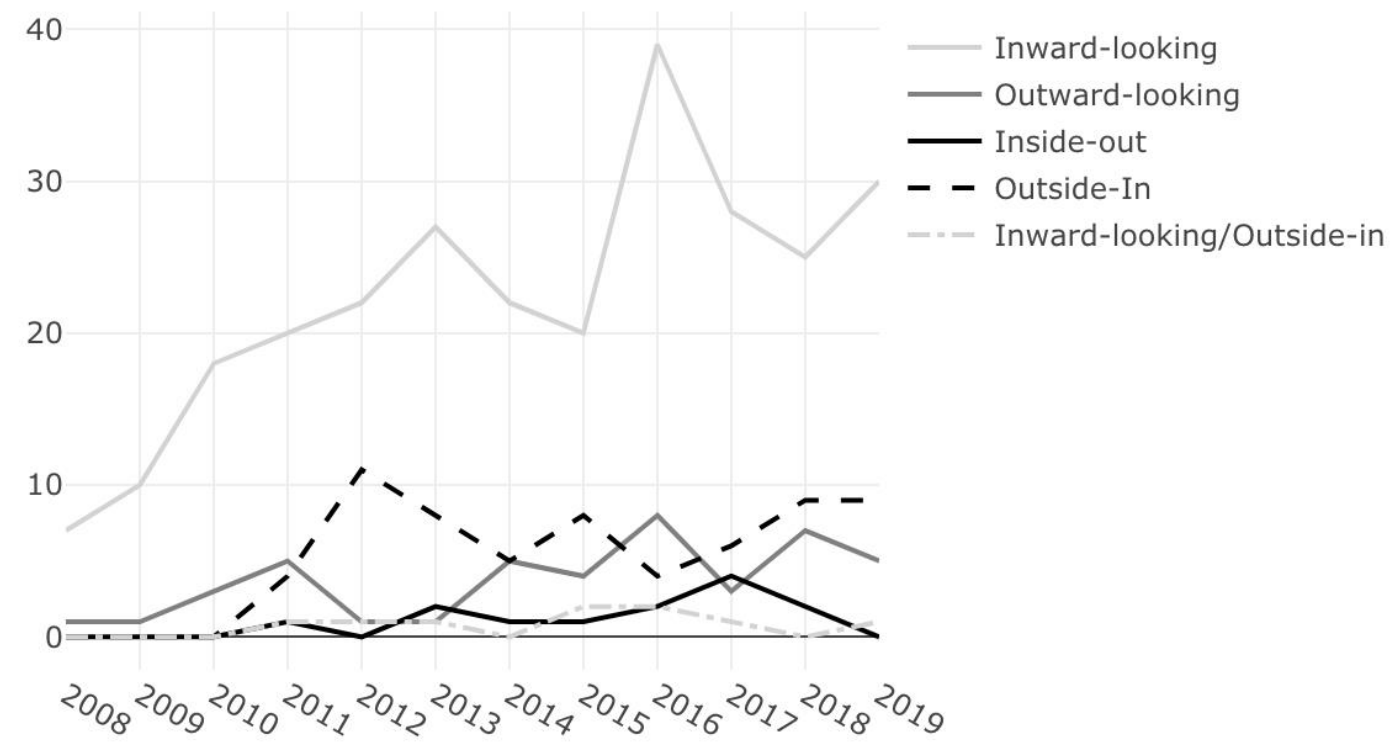

Fig. 4: Development of analytical perspectives over time, 2008 - 2019 (in absolute numbers per year)

Source: Authors' own compilation

Just how much AGR remains a parochial field emphasizing regional affairs despite a global political context becomes apparent when contrasting regional-level with international-level perspectives. Insularity can become problematic if it systematically and continuously excludes perspectives that shine a different light on the issue at hand or may contribute new insights into scope conditions and causal relationships of relevance for understanding and explaining the subject. Under the best of circumstances, parochialism may provide a narrow and incomplete view on the issue, at worst it may 'lead to ignorance, arrogance, and an inability to anticipate the tragic consequences of unreflective analysis' (Biersteker, 2009, p. 324). It can make a 
research community blind to important factors, forces and developments that emerge in the shadow or even outside of conventional research objects.

In the era of the 'new' Arctic characterized by local-global interactions, research should develop with its object to reach a more holistic perspective on Arctic governance in a globalized context. And yet, studies with an inside-out or outwardlooking perspective that take the international level as a relevant arena for Arctic governance remain highly underrepresented. Only three percent of all studies analyse Arctic states' impact on regimes and organizations on the international level with relevance for Arctic governance such as the law of the sea, environmental and ocean governance arrangements, climate governance institutions and international organizations $(n=13)$, whereas eleven percent look at how these affect Arctic affairs in turn ( $n=57)$. The total number of papers in each category with an inside-out or outwardlooking perspective is consistently below ten for all years, though papers with an international focus are more regularly published since 2013.

\section{Discussion}

The recent history of Arctic politics and governance is torn between competing narratives about the broader regional and global consequences that are written into scenarios of Arctic cooperation, integration, discord and confrontation (Dodds \& Nuttall, 2015; Steinberg, Tasch, \& Gerhardt, 2015; Wormbs, 2018). Since the end of the Cold War, the Arctic has maintained a status as a low-tension region that has seen the modernization and additional build-up of armed forces, military posturing and instances of power projection in a direct contact zone between Russia and members of NATO, but not a single shot fired. The Arctic's positive track record shows for instance in the unusual assemblage of state and non-state actors with an especially prominent role for indigenous communities and their collaborative efforts to constantly 
promote environmental protection and sustainable development in the region. Over the past three decades, the eight Arctic states and other global actors have worked actively, collectively and peacefully on the construction of a rule-based order to commonly govern a region of limited statehood.

Where does this leave us in terms of theory and the ability to formulate explanatory accounts of the often inconclusive, conflicting or even contradictory evidence of the forces and outcomes in Arctic politics? One of the major handbooks on IR and the Arctic illustrates the stalemate in theoretical debates about regional affairs. The chapter on the realist school sees ample evidence that '[p]erhaps no current case study better exemplifies the continued explanatory power and relevance of realism as the Arctic region' (Murray, 2014, p. 38). The following chapter on liberal approaches reaches the exact same conclusion, stating that 'connections between international institutions and international law, and the manner in which both intersect with state sovereignty, is perhaps nowhere better exemplified than they are in the Arctic region' (Keating, 2014, p. 70). True, the empirical record of Arctic cooperation is mixed and allows for cherry picking on whatever side of the theoretical table one sits, with an overall stable, cooperative and constantly adapting governance regime at work, while low-level security encounters between Arctic states occasionally occur. Scholarly discussions of how best to explain the past record of Arctic cooperation and what kind of scenario will prevail in the region has neither produced any conclusive empirical results nor merged into new pathways of analytic eclecticism (cf. Sil \& Katzenstein, 2010).

One immediate way out of the deadlock could be achieved through more rigorous application and empirical testing of the grand 'isms' of the IR discipline realism, liberalism and constructivism - that goes beyond simplistic projection of theoretical expectations and, depending on the IR theory in question, a more 
pessimistic or optimistic outlook on the Arctic case. To give one example, Borgerson's much-cited article Arctic meltdown: The economic and security implications of global warming is usually associated with a neorealist reading of international relations in the Arctic, though the article neither self-identifies as neorealist nor deduces and examines any particular assumption from neorealist theory. The only clue that Borgerson resonates with neorealist thinking is his mention of 'anarchy' in one subheading, which, however, he does not use in the sense of a structural condition of a lacking central authority in international politics but to predict the 'sort of armed brinkmanship that plagues other territories' (Borgerson, 2008, p. 71). And yet, it is still within the domain of the grand theories that AGR has so far been most progressive in terms of theoretical contribution to IR. Particularly salient are neoliberal institutionalism and regime theory in their explanation of how common interests, political and economic interdependencies, overlapping institutions and a clear rulebook for regional governance provide strong and persistent means to maintain a peaceful and stable regional order (Byers, 2013; Keil, 2015; Stokke, 2013; Stokke \& Hønneland, 2007; Young, 1994, 1998). Some authors even regard the Arctic as a most-likely case for international cooperation under otherwise unfavourable circumstances. Region-wide rules promoted through common institutions make for a political setting in which expectations are raised that '[i]f Russia and the West cannot co-operate in the Arctic, they cannot co-operate anywhere' (Byers, 2014, also 2017). Other intellectual traditions continue to have a clear impact in the field as well. A large body of constructivist scholarship emphasises the importance of joint cultural bonds, state identities as Arctic companions, regionalism processes and common norms of environmental protection, sustainable development and indigenous rights to autonomy and self-governance for reducing tensions and promoting a sense of belonging to a 
regional community (Dittmer, Moisio, Ingram, \& Dodds, 2011; Keskitalo, 2004; Knecht \& Keil, 2013; Medby, 2018; Neumann, 1994; Wilson, 2007).

Beyond those illustrative examples of research embedded in the conventional IR paradigms, a second promising avenue yet to be explored more thoroughly is to shift away from the grand 'isms' entirely and towards the large corpus of middle-range theories. Theoretical research informed by, for instance, institutionalism, foreign policy analysis, international political economy, bargaining and negotiation theory, critical theory, postcolonialism and poststructuralism, green theory, practice approaches and sociological theory but also non-Western IR theory (though not middle-range in essence) can help to widen the analytical focus, build clearly defined measures of key concepts, better organise the diffuse empirical record and guide causal analysis. Moreover, different schools and traditions could more engage with each other to form a cumulative body of knowledge and avoid a piecemeal approach to empirical analysis. Several scholars very recently made a start and turned in new directions to see through the simultaneous practices of cooperation, integration, fragmentation, dissent and rivalry in the Arctic region by making recourse to concepts and theories from social movement research (Wilson Rowe, 2020), cultural studies (Hansen-Magnusson, 2019), political geography (Dodds, 2019; Dodds \& Woon, 2019; Väätänen, 2019), Foucauldian governmentality (Albert \& Vasilache, 2018) or the philosophy of language (Medby, 2019). These works indicate that the field of AGR is maturing and moving beyond simple description.

Figuratively speaking, Arctic governance is a ship in distress trying to navigate the stormy seas of irreconcilable goal conflicts and costly trade-offs in an increasingly politicised context. Rescue to the Arctic ship can also come from scientific conduct itself through conceptual and theoretical innovation and 'homegrown theorising' still only slowly sought in AGR. There is more to Arctic governance than serving as a 
testing ground for established IR theories. By capitalizing on the abundance of empirical description produced in AGR so far, more causal analysis can provide important insights into how a highly fragmented multi-level governance system maintains order, brokers sets of norms and rules, and constantly develops and adapts social institutions and practices in an emerging and contested political region. As one of the leading scholars in the field notes, the analysis of the two polar regimes, the Arctic and Antarctic, can teach 'useful lessons regarding the importance of institutional innovation, the role of techniques for juggling jurisdictional tensions, the treatment of delicate questions relating to membership, the significance of finding effective means of managing institutional interplay, and the rising need for adaptiveness in a world of complex systems' (Young, 2016, p. 237). One of the great potentials of AGR lies in the prospect to generate innovative insights, new variables and causal relationships previously unknown, underestimated or unspecified in global governance.

In that regard, much is to be gained for theory-development in AGR from more structured comparative research designs across the entire set of relevant actor units and levels of analysis. These can take the form of cross-case comparison, within-case analysis or a combination of the two. Whatever the choice, comparative research designs are less driven by interest in the peculiarities of the case than in specific variables of theoretical interest (cf. George \& Bennett, 2005, Chapter 3). Applying more comparative research designs is a suitable way to utilise the dominance of thick analysis of single cases present in contemporary AGR for theory-development and a means to break open categorically upheld but methodologically often unjustified distinctions, for instance between Arctic and non-Arctic states or between European and Asian observers. There are only five papers in the entire dataset which compare Arctic and non-Arctic actors in some way. Among these is also the only article in the dataset that makes a comparison between an Asian (China) and a European 
(Germany) observer state, in addition to the EU, Canada and the United States (Bartenstein, 2015).

The same goes for comparison of the Arctic with other world regions. More structured cross-case comparison in inter-regional settings would allow for the transfer and diffusion of new ideas, concepts and theories to overcome what von Soest and Stroh have called the "restricted-horizon problem" of confined regional academic communities and discourses' (von Soest \& Stroh, 2018, p. 67). It will further help to demonstrate to what extent the Arctic constitutes a 'normal' region in world politics where the underlying structural, political and institutional components are similar or different to those in other parts of the world. A common comparison is often drawn to the Antarctic, just to find how different the two polar governance regimes are (see particularly Stephens, 2011 on this point). One innovative paper based on a mostsimilar systems design that stands out in our dataset is a comparison of the Arctic Council and the Amazon Cooperation Treaty Organization (ACTO) (Burkhart, McGrath-Horn, \& Unterstell, 2017).

Should cross-case comparison not be viable for methodological reasons, a second option to consider is within-case analysis of the same case at different points in time (Lijphardt, 1971, p. 689). By way of example, rather than analysing each Arctic policy or strategy document anew and in isolation from the previous status quo, casesensitive developments could be analysed over time to lay bare the underlying conditions, changes and continuities in Arctic states' foreign policies (for a recent example outside our sample, see Humrich, 2020). Comparative-historical methods (Mahoney \& Rueschemeyer, 2003), process-tracing (Beach \& Pedersen, 2013) and counterfactual analysis (Tetlock \& Belkin, 1996) are some of the tools for within-case comparison that could help remedy the weaknesses of single-case studies and contribute to strengthened causal analysis, but which have not been applied so far. 


\section{Conclusion}

This review paper has investigated a body of 398 articles published over more than a decade in the field of AGR. AGR has made every effort to better understand Arctic affairs, even if many regional processes and outcomes remain unexplored and unexplained. Having identified academic immaturity, methodological monoculturalism, state-centrism and analytical parochialism as four major weaknesses of AGR, it may be an obvious call to remedy the four limitations by (1) expanding the research focus of AGR towards actors, aspects and actions of the Arctic governance regime that have received insufficient attention in the past, (2) zooming out of the Arctic region to acknowledge and analyse the multi-scalar politics of Northern relations and their embeddedness in international society and institutions of international environmental, climate, energy and security governance, and (3) crossing disciplinary boundaries and widening the methodological toolkit. While we are convinced these steps would be a start to improve status, contribution and reputation of the field, we are also aware this is part of a larger and longer academic process.

The primary purpose of this article then was to raise awareness for some of the shortcomings that persist in AGR despite all the insights and knowledge generated over the past years. There is a need for the field, in Gerring's sense, to further 'mature' regarding the application of structured research designs and sophisticated methods to move forward from merely descriptive accounts to generalizable descriptive and causal inferences for Arctic governance and beyond. While a fair number of recent contributions point in this direction, current research routines and the overall persistence of the four research limitations over more than a decade leaves us to invite the Arctic studies community to continue to undertake more collective efforts for 
methodologically sound, empirically rich and theoretically informed or informing research.

\section{Financial support}

This research received no specific grant from any funding agency, commercial or notfor-profit sectors.

\section{Conflict of interest}

None

\section{References}

Acharya, A. (2014). Global international relations (IR) and regional worlds: A new agenda for international studies. International Studies Quarterly, 58(4), 647659.

Albert, M., \& Vasilache, A. (2018). Governmentality of the Arctic as an international region. Cooperation and Conflict, 53(1), 3-22.

Aydinli, E., \& Biltekin, G. (2018). Widening the World of International Relations: Homegrown Theorizing. Abingdon: Routledge.

Bartenstein, K. (2015). The 'common Arctic': Legal analysis of Arctic \& non-Arctic political discourses. In L. Heininen, H. Exner-Pirot, \& Plouffe, Joël (Eds.), Arctic Yearbook 2015 (pp. 264-280). Akureyri: Northern Research Forum. 
Bates, R. H. (1997). Area studies and the discipline: A useful controversy? PS: Political Science and Politics, 30(2), 166-169.

Beach, D., \& Pedersen, R. B. (2013). Process-Tracing Methods: Foundations and Guidelines. Ann Arbor: University of Michigan Press.

Beier, J. M. (2009). Forgetting, remembering, and finding indigenous peoples in international relations. In J. M. Beier (Ed.), Indigenous Diplomacies (pp. 1127). Basingstoke: Palgrave Macmillan.

Biersteker, T. J. (2009). The parochialism of hegemony: Challenges for "American" international relations. In A. B. Tickner \& O. Wæver (Eds.), International Relations Scholarship around the World (pp. 308-327). London: Routledge.

Blunden, M. (2009). The new problem of Arctic stability. Survival, 51(5), 121-142.

Bognar, D. (2018). The elephant in the room: Article 234 of the Law of the Sea Convention and the Polar Code as an incompletely theorised agreement. The Polar Journal, 8(1), 182-203.

Borgerson, S. G. (2008). Arctic meltdown: The economic and security implications of global warming. Foreign Affairs, 87(2), 63-77.

Brady, A.-M. (2017). China as a Polar Great Power. Cambridge: Cambridge University Press.

Burke, D. C. (2020). Diplomacy and the Arctic Council. Montréal: McGill-Queens University Press.

Burkhart, K., McGrath-Horn, M. C., \& Unterstell, N. (2017). Comparison of Arctic and Amazon regional governance mechanisms. Polar Geography, 40(2), 144-161. Byers, M. (2013). International Law and the Arctic. Cambridge: Cambridge University Press. 
Byers, M. (2014, May 1). Squeeze Putin, yes, but the Arctic is not Ukraine. The Globe and Mail. https://www.theglobeandmail.com/opinion/squeeze-putin-butthe-arctic-is-not-ukraine/article18348971/

Byers, M. (2017). Crises and international cooperation: An Arctic case study. International Relations, 31(4), 375-402.

Dingwerth, K., \& Pattberg, P. (2006). Global governance as a perspective on world politics. Global Governance, 12(2), 185-203.

Dittmer, J., Moisio, S., Ingram, A., \& Dodds, K. (2011). Have you heard the one about the disappearing ice? Recasting Arctic geopolitics. Political Geography, 30(4), 202-214.

Dodds, K. (2018). Global Arctic. Journal of Borderlands Studies, 33(2), 191-194.

Dodds, K. (2019). Geopolitics and ice humanities: Elemental, metaphorical and volumetric reverberations. Geopolitics, OnlineFirst, 1-28.

Dodds, K., \& Nuttall, M. (2015). The Scramble for the Poles: The Geopolitics of the Arctic and Antarctic. Cambridge: Polity Press.

Dodds, K., \& Woon, C. Y. (2019). Triumphant geopolitics? Making space of and for Arctic geopolitics in the Arctic Ocean. In N. Sellheim, Y. V. Zaika, \& I. Kelman (Eds.), Arctic Triumph: Northern Innovation and Persistence (pp. 163-180). Cham: Springer International.

Durfee, M., \& Johnstone, R. L. (2019). Arctic Governance in a Changing World. Lanham: Rowman \& Littlefield.

Eriksen, T. H., Valkonen, S., \& Valkonen, J. (2019). Knowing from the Indigenous North: Sámi Approaches to History, Politics and Belonging. Abingdon: Routledge.

Evengård, B., Larsen, J. N., \& Paasche, Ø. (Eds.). (2015). The New Arctic. Heidelberg: Springer. 
Exner-Pirot, H., \& Murray, R. W. (2017). Regional order in the Arctic: Negotiated exceptionalism. Politik, 20(3), 47-64.

Forbis Jr., R., \& Hayhoe, K. (2017). Does Arctic governance hold the key to achieving climate policy targets? Environmental Research Letters.

George, A., \& Bennett, A. (2005). Case Studies and Theory Development in the Social Sciences. Cambridge: MIT Press.

Gerring, J. (2007). Case Study Research: Principles and Practices. Cambridge: Cambridge University Press.

Gerring, J. (2012). Mere description. British Journal of Political Science, 42(4), 721746.

Goertz, G., \& Mahoney, J. (2012). A Tale of Two Cultures: Qualitative and Quantitative Research in the Social Sciences. Princeton: Princeton University Press.

Grant, S. D. (2010). Polar Imperative: A History of Arctic Sovereignty in North America. Vancouver: Douglas\&Mclntyre.

Grydehøj, A. (2014). Constructing a centre on the periphery: Urbanization and urban design in the island city of Nuuk, Greenland. Island Studies Journal, 9(2), 205-222.

Hansen-Magnusson, H. (2019). Arctic geopoetics: Russian politics at the North Pole. Cooperation and Conflict, 54(4), 466-487.

Heininen, L. (2011). Arctic Strategies and Policies: Inventory and Comparative Study. Akureyri: The Northern Research Forum.

Heininen, L., \& Southcott, C. (Eds.). (2010). Globalization and the Circumpolar North. Fairbanks: University of Alaska Press.

Herrmann, T. M., \& Martin, T. (Eds.). (2016). Indigenous Peoples' Governance of Land and Protected Territories in the Arctic. Cham: Springer International. 
Hønneland, G. (2016). Russia and the Arctic: Environment, Identity and Foreign Policy. London: I.B.Tauris.

Hua, W., Yuan, S., Yan, M., \& Li, Y. (2012). A quantitative analysis of Arctic related articles in the humanities and social sciences appearing in the world core journals. Scientometrics, 91(3), 703-718.

Humrich, C. (2020). Norway's High North geopolitics: Continuities and changes through three decades. In J. Weber (Ed.), Handbook on Geopolitics and Security in the Arctic: The High North Between Cooperation and Confrontation (pp. 57-75). Cham: Springer International.

Keating, T. (2014). International institutions and state sovereignty. In R. W. Murray \& A. D. Nuttall (Eds.), International Relations and the Arctic: Understanding Policy and Governance (pp. 51-78). Amherst: Cambria.

Keil, K. (2015). Spreading oil, spreading conflict? Institutions regulating Arctic oil and gas activities. The International Spectator, 50(1), 85-110.

Keil, K., \& Knecht, S. (Eds.). (2017a). Governing Arctic Change: Global Perspectives. Basingstoke: Palgrave MacMillan.

Keil, K., \& Knecht, S. (2017b). Introduction: The Arctic as a globally embedded space. In K. Keil \& S. Knecht (Eds.), Governing Arctic Change: Global Perspectives (pp. 1-18). Basingstoke: Palgrave MacMillan.

Keohane, R. O. (2009). Political science as a vocation. PS: Political Science and Politics, 42(2), 359-363.

Keskitalo, E. C. H. (2004). Negotiating the Arctic: The Construction of an International Region. London: Routledge.

Keuleers, F., Fonck, D., \& Keukeleire, S. (2016). Beyond EU navel-gazing: Taking stock of EU-centrism in the analysis of EU foreign policy. Cooperation and Conflict, 51(3), 345-364. 
King, G., Keohane, R. O., \& Verba, S. (1994). Designing Social Inquiry: Scientific Inference in Qualitative Research. Princeton: Princeton University Press.

Knecht, S. (2017a). Exploring different levels of stakeholder activity in international institutions: Late bloomers, regular visitors, and overachievers in Arctic Council working groups. In K. Keil \& S. Knecht (Eds.), Governing Arctic Change: Global Perspectives (pp. 163-185). Basingstoke: Palgrave Macmillan.

Knecht, S. (2017b). The politics of Arctic international cooperation: Introducing a dataset on stakeholder participation in Arctic Council meetings, 1998 - 2015. Cooperation and Conflict, 52(2), 203-223.

Knecht, S., \& Keil, K. (2013). Arctic geopolitics revisited: Spatialising governance in the circumpolar North. The Polar Journal, 3(1), 178-203.

Koivurova, T. (2012). The Arctic Council: A testing ground for new international environmental governance. Brown Journal of World Affairs, 19(1), 131-144.

Kopra, S. (2013). China's Arctic interests. In L. Heininen, H. Exner-Pirot, \& J. Plouffe (Eds.), Arctic Yearbook 2013 (pp. 107-124). Akureyri: Northern Research Forum.

Kraska, J. (Ed.). (2011). Arctic Security in an Age of Climate Change. Cambridge: Cambridge University Press.

Lagutina, M., \& Leksyutina, Y. (2019). BRICS countries' strategies in the Arctic and the prospects for consolidated BRICS agenda in the Arctic. The Polar Journal, $9(1), 45-63$.

Landriault, M., Chater, A., Wilson Rowe, E., \& Lackenbauer, P. Whitney. (2019). Governing Complexity in the Arctic Region. London: Routledge. 
Landriault, M., \& Minard, P. (2016). Does standing up for sovereignty pay off politically? Arctic military announcements and governing party support in Canada from 2006 to 2014. International Journal, 71(1), 41-61.

Lijphardt, A. (1971). Comparative politics and the comparative method. American Political Science Review, 65(3), 682-693.

Loukacheva, N. (2010). Arctic governance. In N. Loukacheva (Ed.), Polar Law Textbook (pp. 125-146). Copenhagen: Nordic Council of Ministers.

Lundestad, I., \& Tunsjø, Ø. (2015). The United States and China in the Arctic. Polar Record, 51(4), 392-403.

Mahoney, J., \& Rueschemeyer, D. (Eds.). (2003). Comparative Historical Analysis in the Social Sciences. Cambridge: Cambridge University Press.

Medby, I. A. (2018). Articulating state identity: 'Peopling' the Arctic state. Political Geography, 62, 116-125.

Medby, I. A. (2019). Language-games, geography, and making sense of the Arctic. Geoforum, 107, 124-133.

Murray, R. W. (2014). Westphalian sovereignty and realism in contemporary international security. In R. W. Murray \& A. D. Nuttall (Eds.), International Relations and the Arctic: Understanding Policy and Governance (pp. 25-50). Amherst: Cambria.

Neumann, I. B. (1994). A region-building approach to Northern Europe. Review of International Studies, 20(1), 53-74.

Nuttall, M. (1998). Protecting the Arctic: Indigenous Peoples and Cultural Survival. Amsterdam: Harwood Academic Publishers.

Olsen, I. H., \& Shadian, J. M. (2018). Greenland and the Arctic Council: Subnational regions in a time of Arctic westphalianisation. In K. S. Kristensen \& J. RahbekClemmensen (Eds.), Greenland and the International Politics of a Changing 
Arctic Postcolonial Paradiplomacy between High and Low Politics. Abingdon: Routledge.

Østerud, Ø., \& Hønneland, G. (2014). Geopolitics and international governance in the Arctic. Arctic Review on Law and Politics, 5(2), 156-176.

Parsons, J., Dinwoodie, J., \& Roe, M. (2011). Northern opportunities: A strategic review of Canada's Arctic icebreaking services. Marine Policy, 35(4), 549556.

Pelaudeix, C. (2014). What is Arctic governance? A critical assessment of the diverse meanings of "Arctic governance". In G. Alfredsson, T. Koivurova, \& H. Ó. Ágústsson (Eds.), The Yearbook of Polar Law, Vol. 6 (pp. 398-426). Leiden: Brill.

Ragin, C. C. (2008). Redesigning Social Inquiry: Fuzzy Sets and Beyond. Chicago: University of Chicago Press.

Rosenau, J. N. (1995). Governance in the twenty-first century. Global Governance, 1(1), 13-43.

Rottem, S. V. (2017). The use of Arctic science: POPs, Norway and the Stockholm Convention. Arctic Review on Law and Politics, 8, 246-269.

Sergunin, A., \& Konyshev, V. (2014). Russia in search of its Arctic strategy: Between hard and soft power? The Polar Journal, 4(1), 69-87.

Sil, R., \& Katzenstein, P. J. (2010). Beyond Paradigms: Analytic Eclecticism in the Study of World Politics. Basingstoke: Palgrave MacMillan.

Steinberg, P. E., Tasch, J., \& Gerhardt, H. (2015). Contesting the Arctic: Rethinking Politics in the Circumpolar North. London: I.B.Tauris.

Stephens, T. (2011). The Arctic and Antarctic regimes and the limits of polar comparativism. German Yearbook of International Law, 54, 315-349. 
Stokke, O. S. (2013). Regime interplay in Arctic shipping governance: Explaining regional niche selection. International Environmental Agreements: Politics, Law and Economics, 13(1), 65-85.

Stokke, O. S., \& Hønneland, G. (Eds.). (2007). International Cooperation and Arctic Governance: Regime Effectiveness and Northern Region Building. Abingdon: Routledge.

Stone, D. P. (2015). The Changing Arctic Environment: The Arctic Messenger. Cambridge: Cambridge University Press.

Stubb, A. (2009). A new Arctic era and Finland's Arctic policy. Keynote Speech in the 20th Anniversary Seminar of the Arctic Centre. http://arcticcentre.ulapland.fi/docs/20_Stubb_Arktinenkeskus29092009.pdf Temby, O. (2015). What are levels of analysis and what do they contribute to international relations theory? Cambridge Review of International Affairs, 28(4), 721-742.

Tetlock, P. E., \& Belkin, A. (Eds.). (1996). Counterfactual Thought Experiments in World Politics: Logical, Methodological, and Psychological Perspectives. Princeton: Princeton University Press.

Väätänen, V. (2019). Securing anticipatory geographies: Finland's Arctic strategy and the geopolitics of international competitiveness. Geopolitics, OnlineFirst, 1-24. VanderBerg, J. D. (2018). Optimal Arctic port locations: A quantitative composite multiplier analysis of potential sites. Polar Geography, 41(1), 55-74.

von Soest, C., \& Stroh, A. (2018). Comparisons across world regions: Managing conceptual, methodological, and practical challenges. In A. I. Ahram, P. Köllner, \& R. Sil (Eds.), Comparative Area Studies: Methodological Rationales and Cross-regional Applications (pp. 66-84). Oxford: Oxford University Press. 
Wæver, O. (2017). Afterword: The Arctic security constellation. Politik, 20(3), 121136.

Wilson, E. (2007). Arctic unity, Arctic difference: Mapping the reach of Northern discourses. Polar Record, 43(2), 125-133.

Wilson Rowe, E. (2020). Analyzing frenemies: An Arctic repertoire of cooperation and rivalry. Political Geography, 76, 102072.

Wormbs, N. (Ed.). (2018). Competing Arctic Futures: Historical and Contemporary Perspectives. Basingstoke: Palgrave Macmillan.

Young, O. R. (1994). International Governance: Protecting the Environment in a Stateless Society. Ithaca: Cornell University Press.

Young, O. R. (1998). Creating Regimes: Arctic Accords and International Governance. Ithaca: Cornell University Press.

Young, O. R. (2016). Governing the antipodes: International cooperation in Antarctica and the Arctic. Polar Record, 52(2), 230-238.

Young, O. R. (2019). Constructing the "new" Arctic: The future of the circumpolar North in a changing global order. Outlines of Global Transformations, 12(5), $6-24$.

Young, O. R., Berkman, P. A., \& Vylegzhanin, A. N. (Eds.). (2020). Governing Arctic Seas: Regional Lessons from the Bering Strait and Barents Sea, Volume 1. Cham: Springer International.

Yurdusev, A. N. (1993). "Level of analysis" and "unit of analysis": A case for distinction. Millennium, 22(1), 77-88.

Zellen, B. S. (2009). On Thin Ice: The Inuit, the State, and the Challenge of Arctic Sovereignty. Plymouth: Lexington Books. 
